институту выборов в нашей стране, а, следовательно, имеется потенциал готовности пассивной части молодежи для оказания влияния на политические процессы в нашей стране.

Для того чтобы стимулировать электоральное поведение молодежи органам местного самоуправления следует постоянно и систематически проводить разъяснительную работу с данной категорией населения в самых различных формах. Это может быть организация массовых мероприятий с участием молодежных активистов; создание политических, социокультурных, организационных, социальнополитических условий для самореализации молодых граждан в предвыборный период; разработка и реализация социально-значимых проектов, направленных на улучшение жизненных условий молодежи. Главный принцип работы при этом - систематичность, отсутствие формализма, искренняя вера руководства района, в то, что молодежь определяет будущее страны, оказание реального содействия развитию потенциальных способностей и возможностей молодых избирателей, помощь и поддержка со стороны органов местного самоуправления в решении наиболее острых проблем молодежи.

$$
* * *
$$

1. Собрание законодательства РФ. 17.06.2002. N 24. Ст. 2253.

2. Гриб В. В. Система избирательных комиссий РФ как объект общественного контроля // Конституционное и муниципальное право. 2016. N 11. С. 42 - 46.

3. Пресс-выпуск № 3202 Всероссийского центра исследования общественного мнения (ВЦИОМ) [электронный pecypc] // Режим доступа: http://www.wciom.ru

4. Официальный сайт Фонда «Общественное мнение» (ФОМ) [электронный ресурс] // Режим доступа: http://fom.ru

5. Официальный сайт Всероссийского центра исследования общественного мнения (ВЦИОМ) [электронный ресурс] // Режим доступа: http://wciom.ru/.

6. Официальный сайт Всероссийского центра исследования общественного мнения (ВЦИОМ) [электронный ресурс] // Режим доступа: http://2017.vybor-naroda.org/lentanovostey/99704-vciombolshinstvo-rossiyan-vystupaet-za-uchastie-molodezhi-v-politike-no-ne-v-mitingah.html

7. Официальный сайт Избирательной комиссии Ставропольского края [электронный ресурс] // Режим доступа: http://www.stavropol.izbirkom.ru/news/1506/

\title{
Трубкина Е.И., Саблин Д.А. \\ Современные тенденции развития и функционирования институтов защиты прав и свобод человека и гражданина в Российской Федерации
}

doi:10.18411/spc-20-10-2017-10

idsp: 000001:spc-20-10-2017-10

Права и свободы человека и гражданина являются наивысшей ценностью государства, что отражено в статье 2 Конституции Российской Федерации, вторая глава которой полностью посвящена закреплению основных прав и свобод. Стоит отметить, что данные идеи признаны международным сообществом и отражены в таких актах, как Всеобщая декларация прав человека от 10 декабря 1948 г., Международный пакт о гражданских и политических правах от 16 декабря 1996 г. и иных актах. Все перечисленные акты активно используются и применяются при защите прав и свобод человека не только на международном уровне, но и в Российской Федерации.

Безусловно, одного признания и закрепления прав и свобод человека и гражданина в законодательстве страны недостаточно. Осуществление прав и свобод лицом может происходить непосредственно либо опосредованно, то есть, для их беспрепятственной реализации и устранения помех в их претворении в жизнь государством создаются и функционируют специально на то уполномоченные органы. Из этого следует, что признания и закрепления прав и свобод в законодательстве страны недостаточно. Важно обеспечить их наиболее полное осуществление.

Однако не стоит исключать и факта нарушения прав, что должно повлечь устранение таковых неправомерных действий. В теории принято выделять следующие 
группы институтов защиты установленных на законодательном уровне прав и законных интересов граждан: судебная система; государственные институты внесудебной защиты; неправительственные правозащитные институты. При этом, каждая группа объединяет в себе совокупность тех или иных институтов защиты прав и свобод. Уделяя внимание изучению функционирования подобных элементов на территории Российской Федерации, видится необходимым раскрыть составляющие указанных групп более подробно.

Итак, изучая первую группу - судебную систему, следует отметить, что она представлена в России системой судов как общей юрисдикции, так и арбитражных судов, а равно Конституционным судом Российской Федерации и конституционными (уставными) судами субъектов Российской Федерации, с учетом специфики деятельности трех последних, остановимся на анализе осуществления правосудия системой судов общей юрисдикции.

Судопроизводству отведена отдельная XII Глава Конституции Российской Федерации. Действует и ряд нормативно-правовых актов, таких как ФКЗ «О судебной системе Российской Федерации», ФКЗ «О судах общей юрисдикции в Российской Федерации», регулирующих функционирование судебной системы в целом. Суть данного института защиты прав и свобод выражается в том, что каждому на территории России гарантировано право на судебную защиту своих прав и законных интересов вне зависимости от пола, расы и национальности, а равно иных аспектов, что отражено в статье 46 Конституции Российской Федерации.

Вторая группа олицетворяет взаимодействие органов государственной власти и органов местного самоуправления, чья деятельность направлена, в первую очередь, на обеспечение беспрепятственной реализации прав и свобод человека и гражданина. В их число входят органы исполнительной, законодательной власти, а также органы местного самоуправления.

Так, законодательные органы и на федеральном, и на региональном уровне, принимают соответствующие нормативные акты, как раз позволяющие защищать права и свободы, например, Ф3 «О персональных данных» регламентирует процесс получения и обработки персональных данных с целью нераспространения личной информации в массах, право на которые закреплено в части 1 ст. 24Конституции Российской Федерации. В свою очередь, органы исполнительной власти в силу возложенных на них законом полномочий устраняют нарушения прав, правомочны принимать акты в отношении отдельных лиц в целях пресечения неправомерных действий, например, возбуждение уголовного дела по факту распространения лицом личной информации (тайны), что устанавливается статьей 137 Уголовного Кодекса Российской Федерации.

Органы местного самоуправления, также своими действиями могут способствовать защите прав. Например, при установке рекламного баннера был закрыт обзор из окна многоэтажного дома, ввиду чего Администрация муниципального образования вправе вынести предписание об устранении данного нарушения.

Однако сегодня наибольший интерес вызывает именно третья группа, включающая в себя институт Уполномоченного по правам человека. Должность Уполномоченного впервые в России была введена в 1993 г. Конституцией Российской Федерации (п. «е», ч. 1, ст. 103). Уполномоченным по правам человека в Российской Федерации с 22 апреля 2016 года является Москалькова Татьяна Николаевна. Деятельность регламентируется ФКЗ «Об Уполномоченном по правам человека в Российской Федерации». Его основной сферой деятельности является рассмотрение жалоб граждан России и находящихся на её территории иностранных граждан и лиц без гражданства на решения, действия либо бездействие государственных органов, органов местного самоуправления и их должностных лиц. Однако его деятельность только дополняет существующие средства защиты прав и свобод, при этом, не отменяет и не влечет пересмотра компетенции государственных органов, которые также обеспечивают защиту и восстановление нарушенных прав. 
Должность существует и в регионах страны (региональные омбудсмены). В связи с возрастанием интереса и продуктивности деятельности Уполномоченного по правам человека, вскоре появились уполномоченные по правам ребенка, по правам предпринимателей, по правам студентов, что, несомненно, говорит о возрастании значимости данного института в области защиты прав и свобод человека и гражданина.

Безусловно, и ряд таких институтов, входящих в третью группу, как общественные объединения (общественные организации, политические партии и иные формы) позволяют гражданам России, действуя на основании Ф3 «Об общественных объединениях», объединяясь для реализации своих определенных целей, исключая прямое вмешательство государства и органов местного самоуправления, осуществлять в том числе и защиту своих прав и законных интересов. Например, политические партии, руководствуясь положениями Ф3 «О политических партиях», разрабатывают свои программы таким образом, что они будут отражать в перспективе улучшение в той или иной сфере, например, в области образования и медицины, преобразование экономической ситуации в стране, что тесно связано с правами и свободами населения, в том числе с правом на бесплатную медицинскую помощь (ст. 41 Конституции Российской Федерации). В статье 30 Конституции Российской Федерации также говорится о том, что «каждый имеет право на объединение, включая право создавать профессиональные союзы для защиты своих интересов».

Таким образом, подводя итог вышеизложенного, стоит еще раз отметить то, что сегодня на территории Российской Федерации существуют и продуктивно функционируют такие институты защиты прав и свобод, как Уполномоченный по правам человека, судебная система, органы власти и МСУ, что позволят говорить о достаточно высоком уровне защиты законных интересов граждан и иных лиц, пребывающих на территории государства, а равно граждан Российской Федерации, находящихся за пределами страны.

Так же стоит отметить высокий уровень функционирования институтов защиты прав и свобод человека и гражданина в Российской Федерации. В Российском обществе создаются все условия для самореализации и автономии личности, исключающие любое вмешательство в жизнь индивида, позволяющие ему руководствоваться исключительно своими частными интересами. В свою очередь, государство гарантирует осуществление всех прав и свобод человека и гражданина в повседневной жизни.

$$
* * *
$$

1. Всеобщая декларация прав человека (принята Генеральной Ассамблеей ООН 10.12.1948) // Российская газета. - 1995. - N 67.

2. Международный пакт о гражданских и политических правах (Принят 16.12.1966 Резолюцией 2200 (XXI) на 1496-ом пленарном заседании Генеральной Ассамблеи ООН) // Ведомости ВС СССР. 1976. - N 17. - Ст. 291

3. Конституция Российской Федерации (принята всенародным голосованием 12.12.1993) // Российская газета. - 1993. - N 237 (ред. от 21.07.2014 // Собрание законодательства РФ. - 2014. - N 30. - Ст. 4202).

4. Федеральный конституционный закон от 31.12.1996 N 1-ФКЗ «О судебной системе Российской Федерации» // Собрание законодательства РФ. - 1997. - N 1. - Ст. 1 (ред. от 05.02.2014 // Собрание законодательства РФ. - 2014. - N 6. - Ст. 551).

5. Федеральный конституционный закон от 26.02.1997 N 1-ФКЗ «Об Уполномоченном по правам человека в Российской Федерации»// Собрание законодательства РФ. - 1997. - N 9. - Ст. 1011 (ред. от 31.01.2016 // Собрание законодательства РФ. - 2016. - N 5. - Ст. 552).

6. Федеральный закон от 19.05.1995 N 82-Ф3 «Об общественных объединениях» // Собрание законодательства РФ. - 1995. - N 21. - Ст. 1930 (ред. от 02.06.2016 // Собрание законодательства РФ. - 2016. - N 23. - Ст. 3303).

7. Федеральный закон от 26.10.2003 N 131-Ф3 «Об общих принципах организации местного самоуправления в Российской Федерации» // Собрание законодательства РФ. - 2003. - N 40. - Ст. 3822 (ред. от 29.07.2017 // Собрание законодательства РФ. - 2017. - N 31. - Ст. 4828).

8. Бадальянц Ю.С., Ягофаров Д.А. Права человека: учебное пособие. - М.: Поверенный. - 2015. - 519 c. 